\title{
Assessment of chlorophyll and water quality using remote sensing and GIS imagery in the Cauvery watershed of Karnataka, India
}

\author{
D. KARUNAKARAN ${ }^{1,2}$, S. K. SAHU ${ }^{1}$, ARUN PANDIT ${ }^{1}$ AND A. P. SHARMA ${ }^{3}$ \\ ${ }^{1}$ ICAR-Central Inland Fisheries Research Institute, Barrackpore, Kolkata - 700 120, West Bengal, India \\ ${ }^{2}$ ICAR-Central Island Agricultural Research Institute, Port Blair - 744101, Andaman and Nicobar Islands, India \\ ${ }^{3}$ G. B. Pant University of Agriculture and Technology, Pantnagar, Udham Singh Nagar - 263145 \\ Uttarakhand, India \\ e-mail: karunakaran_tn@rediffmail.com
}

\begin{abstract}
India has vast inland water resources having immense potential for aquaculture. Assessment of water quality parameters is a pre-requisite to any scientific intervention as they are of prime importance in fisheries perspective. However, monitoring water quality parameters of such vast area is not an easy task with the conventional tools and methods. In the present study, water quality parameters and chlorophyll pigment concentration were assessed using IRS P-6 remote sensing imagery in the Cauvery watershed of Karnataka State, India. Images captured by optical satellite sensors are often obscured by atmospheric effects. Hence, the images were rectified by Dark pixel subtraction method before analysing data in order to extract useful information from the imagery. The study revealed that there was significant correlation between spectral reflectance and in-situ water quality parameters. Near infra-red band $(0.77-0.86 \mu \mathrm{m})$, was useful to assess the water quality parameters like depth, specific conductivity, total alkalinity, chlorinity, salinity and turbidity. Similarly, short wave infrared band (1.55-1.70 $\mu \mathrm{m})$ was useful for assessing chlorophyll-a. However, the models were found to be region specific and they appear to have potential for monitoring water quality of large water bodies at regular intervals.
\end{abstract}

Keywords: Cauvery watershed, Chlorophyll a, IRS P-6, Remote Sensing, Water quality

\section{Introduction}

India has a total water spread area of about $314,400 \mathrm{~km}^{2}$ which includes vast inland water resources in the form of rivers, canals, reservoirs, lakes, tanks, ponds, beels, oxbow lakes, derelict water bodies and brackishwater areas. As per the Ministry of Water Resources, Government of India (MWR, 2013), the total inland water area excluding rivers and canals is about 7 million ha. India has over 19000 reservoirs covering around 3.15 million ha area. Small reservoirs account for $99 \%$ of the total reservoirs and covers $47.11 \%$ of the countries reservoir area. Large reservoirs, though small in number (56), cover $36.16 \%$ of the total reservoir area (Sugunan, 1995).

Reservoirs are called the sleeping giants of Indian fisheries owing to their huge potential of fish production. Proper scientific management of this resource can yield substantial fish production. Assessment of water quality parameters is the pre-requisite to any scientific intervention as they are of prime importance in fisheries perspective. However, monitoring water quality parameters of such vast area is not an easy task with the conventional tools and methods. However, with the advent of Geographical
Information System (GIS) and Remote Sensing imageries, assessment of water quality parameters is possible within a short period of time. The present study is an effort in this direction, where water quality parameters and chlorophyll pigment concentration were assessed using IRS P-6 remote sensing imagery on a GIS platform in the Cauvery watershed of Karnataka State of India.

Remote sensing is a very cost effective tool for rapid and effective assessment of large areas of the earth's features. Imageries are very cheap and even free data are available to monitor fisheries habitats, rivers, reservoirs and wetlands. Many reports are already available to assess water quality parameters from optical remote sensing since 1970s. Ritchie et al. (1974) developed an early empirical approach to estimate the suspended sediments. A few reports are available on remote sensing as a powerful tool which could be applied to regional water quality monitoring and assessment (Ritchie and Charles, 1988; Schalles et al., 1998; Chopra et al., 2001; Dekker et al., 2002; Chen et al., 2007; Syahreza, et al., 2012). Satellite remote sensing can serve as a fast and relatively cost-effective tool for early and expeditious assessment of the spatial and temporal variability of lake water quality conditions (Zilioli and Brivio, 1997). Many studies have demonstrated reliable 
relationships between water quality parameters, such as total phosphorus, total nitrogen, dissolved oxygen, $\mathrm{pH}$, salinity, Secchi depth, sodium, potassium and radiance data from the satellites (Dewidar and Khedr, 2001; Alparslan et al., 2007). The econometric tool of regression technique has strong potential for the application of Indian Remote Sensing (IRS) data in monitoring water quality parameters of inland waters (Choubey, 1997). Fraser (1998) demonstrated the relationship between remotely sensed data and turbidity of a specific water body. Remote sensing techniques can be used to monitor water quality parameters such as suspended sediments (turbidity), chlorophyll and temperature (Ritchie et al., 2003). A cost-effective remote sensing-based methodology was developed to predict water quality parameters namely chlorophyll-a, turbidity and phosphorus using Landsat spectral data and a neural network (Chebud et al., 2012). Gholizadeh et al. (2016) systematically reviewed water quality parameters estimation using space borne, airborne sensors and remote sensing techniques. Many reports are there on use of visible and near infrared bands to assess the relationship between water column reflection and transparency, chlorophyll concentration, organic matters and suspended sediments in different water bodies (Ritchie et al., 2003; El-Din et al., 2013; Giardino et al., 2014; Lim and Choi, 2015). This has been widely used to monitor and map shallow coastal waters (Bierwirth et al., 1993). Akbar et al. (2014) explored Landsat-5 TM satellite data to develop empirical models for Canadian Water Quality Index (CWQI) and turbidity using blue, green, red, and NIR bands. Ouma et al. (2018) predicted optically active water constituents such as chlorophyll-a, turbidity, suspended particulate matter and water colour using smartphone sensor applications and Landsat ETM+ visible and NIR (VNIR) data.

\section{Materials and methods}

Mandya and Hassan Districts of Karnataka in Cauvery basin were identified as the study area to assess chlorophyll and water quality parameters (Fig. 1) during post-monsoon period.

Based on NASA Shuttle Radar Topographic Mission (SRTM), $90 \mathrm{~m}$ digital elevation data, flow paths and watersheds were delineated using TNT Micro Image software. The Cauvery basin encompasses an area of $85349.52 \mathrm{~km}^{2}$, which is nearly $2.5 \%$ of the total geographical area of the country. The catchment of the river basin lies in the states of Karnataka, Tamil Nadu, Kerala and Union Territory of Puducherry. Indian Remote Sensing Satellite, IRS P6 LISS-III multi-spectral data (Fig. 2) dated $20^{\text {th }}$ February 2012 for post-monsoon period were procured from National Remote Sensing Center, Hyderabad, for this study.

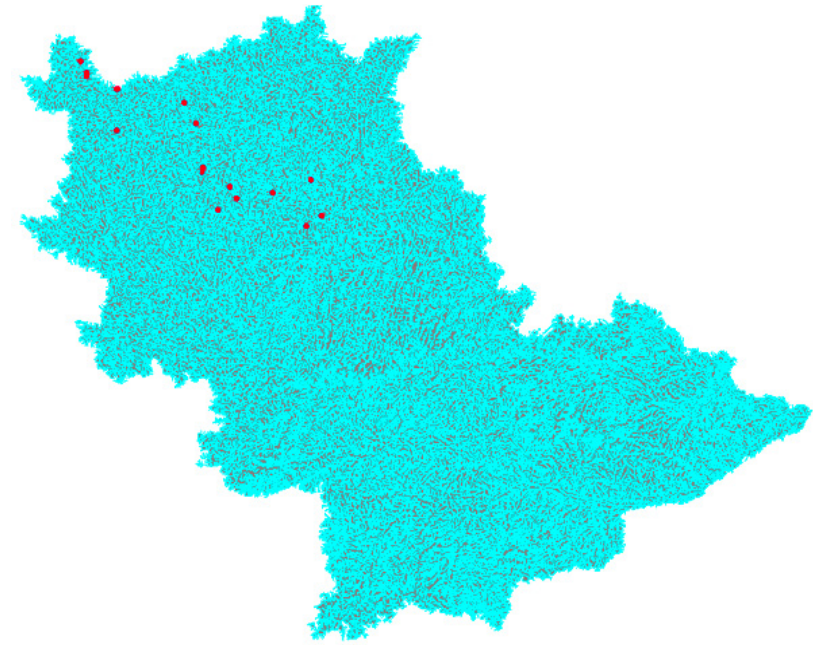

Fig. 1. Cauvery basin delineated based on SRTM DEM data

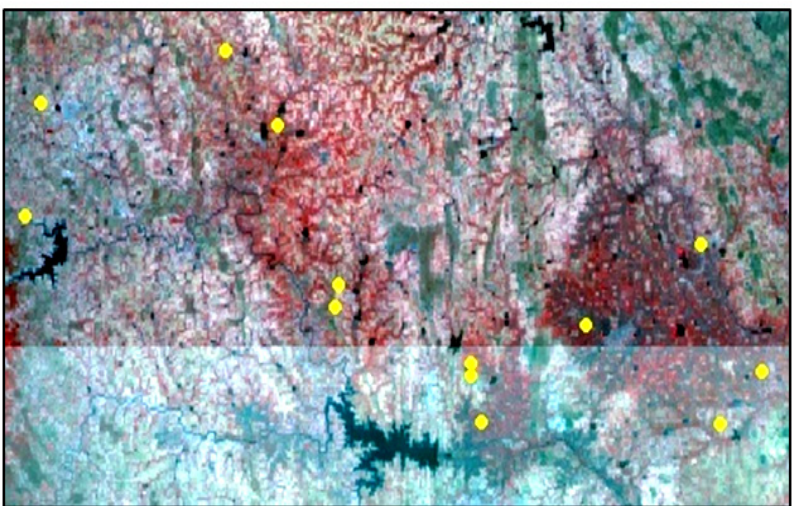

Fig. 2. Partial scene of study area (IRS P-6 image acquired on 20-FEB-2012)

LISS III sensor has four multispectral bands based on wavelengths: green $(0.52-0.59 \mu \mathrm{m})$, red $(0.62-0.68 \mu \mathrm{m})$, near infrared $(0.77-0.86 \mu \mathrm{m})$ and short wave infrared $(1.55-1.70 \mu \mathrm{m})$. It has a spatial resolution of $24 \mathrm{~m}$, temporal resolution of 24 days, radiometric resolution of $7 \mathrm{bit}$ and swath of $141 \mathrm{~km}$ which are useful for this study.

Thirty-one water samples were collected from 19 water bodies having more than 50 ha area across Mandya and Hassan districts of Karnataka in Cauvery River basin during post-monsoon period. The ground truth data were collected exactly during the period of IRS-P6 overpass. Water quality parameters considered in this study are water temperature, transparency, dissolved oxygen (DO), specific conductivity, $\mathrm{pH}$, total dissolved solids (TDS), total alkalinity, free $\mathrm{CO}_{2}$, chlorinity, salinity, $\mathrm{NO}_{3-} \mathrm{N}$, total nitrogen, $\mathrm{PO}_{4}$, sulphate, silicate, hardness, $\mathrm{Ca}, \mathrm{Mg}$, and chlorophyll. The sample collection and analysis were carried out in the laboratory following standard methodology (APHA, 1992). 
The flow chart for getting the corrected DN value is presented in Fig. 3. Initially, water sampling and chlorophyll measurements were conducted concurrent with the Indian Remote-Sensing Satellite (IRS-P6) overpass. Following this, IRS-P6 Liss-III imagery was normalised by removing atmospheric effects and noise using the image processing software, TNT microiamge. Lastly, correlation study was done with rectified satellite reflectance values against in situ water quality parameters and chlorophyll data. Imageries collected by the satellites are generally affected by the disturbance of atmospheric particles through absorption and scattering. This problem is more significant while assessing water quality and chlorophyll in inland waters. These effects can be removed using suitable atmospheric corrections and bi-directional reflectance models (Hadjimitsis and
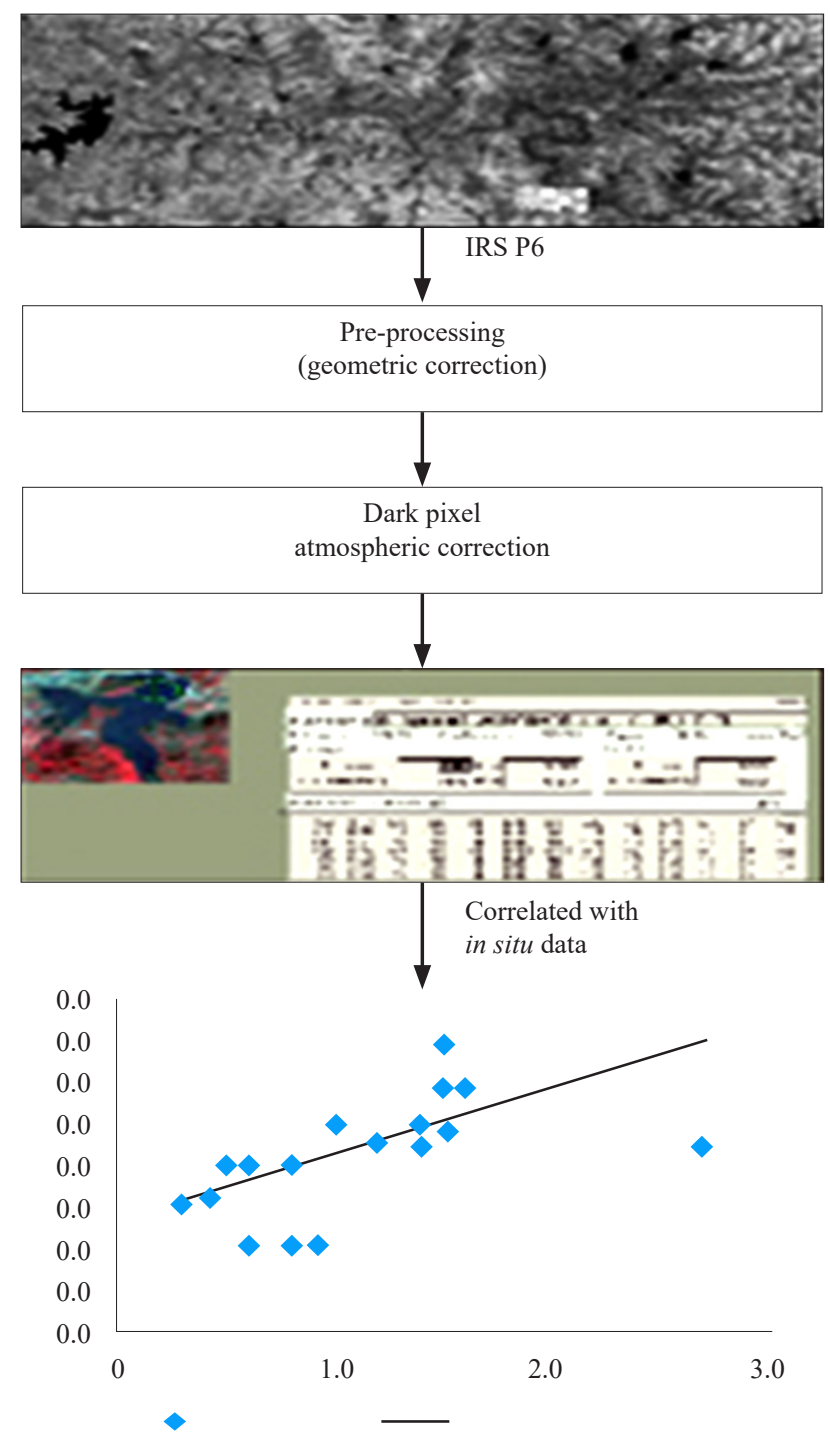

Fig. 3. Methodology for assessing water quality
Clayton, 2008). In this study dark pixel subtraction method has been used to eliminate these effects. IRS P-6 imagery procured for assessing water quality and chlorophyll pigment concentration of study area (Cauvery watershed) were subjected to an atmospheric correction using Dark Pixel subtraction method.

\section{Results and discussion}

Optical remote sensing images are altered by atmospheric effects in visible and near-visible ranges. These effects degrade the quality of image. Atmospheric effects were corrected prior to extract useful information from the imagery following the method already discussed. Table 1 shows the results of impact of rectification.

\section{Correlation with water quality parameters}

The atmospheric corrected spectral reflectance values from all the bands were correlated with in situ water quality and chlorophyll parameters. It is found that there were significant relationship between spectral reflectance (Near Infrared band) and depth $\left(\mathrm{R}^{2}=0.3384, \mathrm{p}<0.01\right.$, $\mathrm{n}=25)$, specific conductivity $\left(\mathrm{R}^{2}=0.4177, \mathrm{p}<0.01, \mathrm{n}=25\right)$, total alkalinity $\left(\mathrm{R}^{2}=0.3145, \mathrm{p}<0.01, \mathrm{n}=25\right)$, chlorinity $\left(\mathrm{R}^{2}=0.3364, \mathrm{p}<0.01, \mathrm{n}=25\right)$ and salinity $\left(\mathrm{R}^{2}=0.3369\right.$, $\mathrm{p}<0.01, \mathrm{n}=25)$. Reflectance values from the green $(0.52-0.59 \mu \mathrm{m})$ and red $(0.62-0.68 \mu \mathrm{m})$, bands did not show correlation with any of the water quality parameters. Highly significant correlation was also found between short wave infrared (1.55-1.70 $\mu \mathrm{m})$ band and chlorophyll a $\left(\mathrm{R}^{2}=0.3722, \mathrm{p}<0.01,25\right)$ and turbidity $\left(\mathrm{R}^{2}=0.3932\right.$, $\mathrm{p}<0.01, \mathrm{n}=25)$. Correlation coefficients for different physico-chemical parameters and chlorophyll with various bands are presented in Table 2 and 3 respectively.

Scatter diagrams were plotted to visually identify relationship between significantly correlated water quality parameters and spectral signature (Fig. 4). The trend line was drawn and linear regression equation was developed by best-fit procedures to predict water quality and chlorophyll parameters. The linear regression models so developed for predicting water quality parameters were: Depth $-\mathrm{y}=-2.0233 \mathrm{x}+45.192, \mathrm{R}^{2}=$ 0.3384 , Specific conductivity - $\mathrm{y}=0.0169 \mathrm{x}+0.2498, \mathrm{R}^{2}$ $=0.4177, \mathrm{p}<0.01, \mathrm{n}=25$, Total alkalinity $-\mathrm{y}=5.2339 \mathrm{x}$ $\left.+108.43, \mathrm{R}^{2}=0.3145, \mathrm{p}<0.01, \mathrm{n}=25\right)$ Chlorinity - $\mathrm{y}=$ $0.0018 \mathrm{x}+0.0095, \mathrm{R}^{2}=0.3364, \mathrm{p}<0.01, \mathrm{n}=25$, Salinity $\mathrm{y}=0.0032 \mathrm{x}+0.0471 \quad \mathrm{R}^{2}=0.3369, \mathrm{p}<0.01, \mathrm{n}=25$ and Turbidity $-\mathrm{R}^{2}=0.3932, \mathrm{p}<0.01, \mathrm{n}=25$.

Scatter diagrams were plotted and regression equation was developed to identify relationship between chlorophyll a and spectral signature (Fig. 5).

The study concludes that IRS P6 LISS III band Near Infrared $(0.77-0.86 \mu \mathrm{m})$ is useful to assess the water quality parameters like depth, specific conductivity, total 
Table 1. Reflectance values of Cauvery reservoirs before and after atmospheric correction (AC) in IRS P6 imagery

\begin{tabular}{|c|c|c|c|c|c|c|c|c|}
\hline \multirow{2}{*}{ Water bodies } & \multicolumn{2}{|c|}{ IRS P6 NIR Band } & \multicolumn{2}{|c|}{ IRS P6 Red Band } & \multicolumn{2}{|c|}{ IRS P6 Green band } & \multicolumn{2}{|c|}{ IRS P6 SWIR Band } \\
\hline & Before AC & After AC & Before AC & After AC & Before AC & After AC & Before AC & After AC \\
\hline Thailuru Kere & 42 & 27 & 41 & 14 & 71 & 13 & 20 & 5 \\
\hline KRS Dam location 1 & 18 & 4 & 29 & 12 & 63 & 19 & 18 & 7 \\
\hline KRS Dam location 2 & 18 & 4 & 29 & 12 & 62 & 18 & 17 & 6 \\
\hline Marehalli Kere location 1 & 29 & 15 & 32 & 15 & 61 & 17 & 20 & 9 \\
\hline Marehalli Kere location 1 & 29 & 15 & 32 & 15 & 64 & 20 & 19 & 8 \\
\hline Hadly Kere & 30 & 16 & 35 & 18 & 67 & 23 & 24 & 13 \\
\hline Deviramani location 1 & 21 & 6 & 34 & 7 & 65 & 7 & 22 & 7 \\
\hline Deviramani location 1 & 23 & 8 & 34 & 7 & 68 & 10 & 21 & 6 \\
\hline Hosaholalu location 1 & 21 & 6 & 31 & 4 & 69 & 11 & 22 & 7 \\
\hline Hosaholalu location 2 & 21 & 6 & 31 & 4 & 69 & 11 & 21 & 6 \\
\hline Tonnuru Kere location 1 & 18 & 3 & 28 & 1 & 59 & 1 & 19 & 4 \\
\hline Tonnuru Kere location 2 & 19 & 4 & 29 & 2 & 60 & 2 & 19 & 4 \\
\hline Kunthi Kere location 1 & 20 & 5 & 32 & 5 & 62 & 4 & 20 & 5 \\
\hline Kunthi Kere location 2 & 21 & 6 & 30 & 3 & 64 & 6 & 20 & 5 \\
\hline Bedigantha location 1 & 24 & 9 & 34 & 7 & 68 & 10 & 22 & 7 \\
\hline Bedigantha location 2 & 23 & 8 & 33 & 6 & 68 & 10 & 23 & 8 \\
\hline Bagur location 1 & 30 & 15 & 37 & 10 & 77 & 19 & 26 & 11 \\
\hline Bagur location 2 & 29 & 14 & 36 & 9 & 72 & 14 & 24 & 9 \\
\hline Kal Kere & 25 & 10 & 40 & 13 & 80 & 22 & 29 & 14 \\
\hline Hunasina Kere location 1 & 30 & 15 & 35 & 8 & 77 & 19 & 26 & 11 \\
\hline Hunasina Kere location 2 & 30 & 15 & 36 & 9 & 74 & 16 & 25 & 10 \\
\hline Hemavathi location 1 & 21 & 6 & 35 & 8 & 73 & 15 & 26 & 11 \\
\hline Hemavathi location 1 & 21 & 6 & 35 & 8 & 76 & 18 & 26 & 11 \\
\hline Konanahalli Kere location 1 & 27 & 12 & 34 & 7 & 65 & 7 & 22 & 7 \\
\hline Konanahalli Kere location 2 & 29 & 14 & 32 & 5 & 66 & 8 & 20 & 5 \\
\hline
\end{tabular}

AC - Atmospheric Correction

Table 2. Correlation coefficients of different physico-chemical parameters with various bands of IRS P6 imagery in Cauvery watershed during post-monsoon

\begin{tabular}{llllll}
\hline Parameters & Correlation & NIR & RED & GREEN & SWIR \\
\hline Depth & Pearson correlation & $-0.582^{* *}$ & -0.509 & -0.510 & -0.345 \\
& Sig. (2 tailed) & 0.0023 & 0.009 & 0.009 & 0.091 \\
& N & 25 & 25 & 25 & 25 \\
\hline Specific conductivity & Pearson correlation & $0.646^{* *}$ & 0.528 & 0.412 & 0.311 \\
& Sig. (2 tailed) & 0.0005 & 0.007 & 0.041 & 0.13 \\
& N & 25 & 25 & 25 & 25 \\
\hline Total alkalinity & Pearson correlation & $0.561^{* *}$ & 0.464 & 0.243 & 0.135 \\
& Sig. (2 tailed) & 0.004 & 0.019 & 0.253 & 0.519 \\
\hline Chlorinity & N & 25 & 25 & 25 & 25 \\
& Pearson correlation & $0.580^{* *}$ & 0.326 & 0.482 & 0.546 \\
& Sig. (2 tailed) & 0.002 & 0.112 & 0.015 & 0.005 \\
Salinity & N & 25 & 25 & 25 & 25 \\
& Pearson correlation & $0.580^{* *}$ & 0.326 & 0.483 & 0.546 \\
& Sig. (2 tailed) & 0.002 & 0.112 & 0.014 & 0.005 \\
\hline Turbidity & $\mathrm{N}$ & 25 & 25 & 25 & 25 \\
\hline & Pearson correlation & 0.208 & 0.057 & 0.327 & $0.627^{* *}$ \\
& Sig. (2 tailed) & 0.32 & 0.788 & 0.111 & 0.001 \\
& $\mathrm{~N}$ & 25 & 25 & 25 & 25 \\
\hline
\end{tabular}

$* * \mathrm{p}<0.01$ 
Table 3. Pearson correlation coefficients of chlorophyll and various bands of IRS P6 imagery in Cauvery watershed during post-monsoon period. $\mathrm{N}=25$; Prob $>|\mathrm{r}|$ under $\mathrm{H} 0$ : Rho $=0$

\begin{tabular}{llllll}
\hline Particulars & $\begin{array}{l}\text { Reflectance value } \\
\text { (SWIR) }\end{array}$ & Chlorophyll a & Chlorophyll b & Chlorophyll c & $\begin{array}{l}\text { Total } \\
\text { Chlorophyll }\end{array}$ \\
\hline Reflectance value (SWIR) & 1.00000 & $0.61006(0.0012)$ & $0.54525(0.0048)$ & $0.31967(0.1193)$ & $0.65689(0.0004)$ \\
Chlorophyll a & $0.61006^{*}(0.0012)$ & 1.00000 & $0.93410(<.0001)$ & $0.32711(0.1105)$ & $0.88766(<.0001)$ \\
Chlorophyll b & $0.54525(0.0048)$ & $0.93410(<.0001)$ & 1.00000 & $0.40434(0.0450)$ & $0.96428(<.0001)$ \\
Chlorophyll c & $0.31967(0.1193)$ & $0.32711(0.1105)$ & $0.40434(0.0450)$ & 1.00000 & $0.44134(0.0272)$ \\
Total Chlorophyll & $0.65689^{*}(0.0004)$ & $0.88766(<.0001)$ & $0.96428(<.0001)$ & $0.44134(0.0272)$ & 1.00000 \\
\hline
\end{tabular}

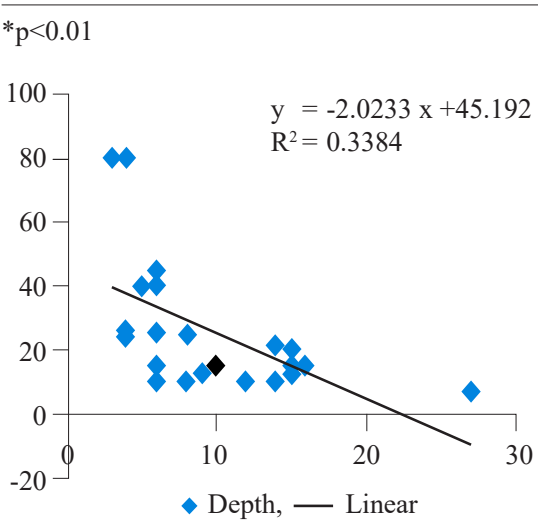

(a)

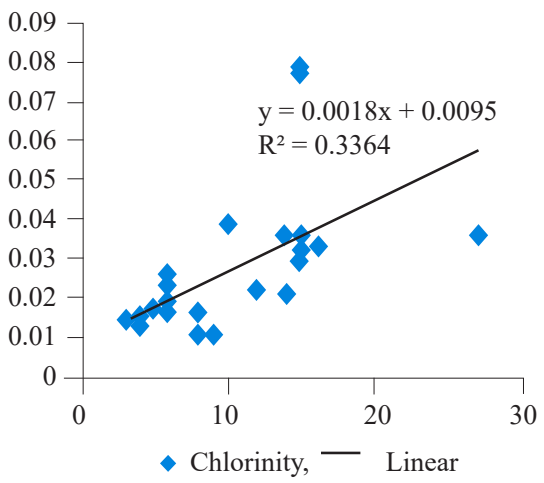

(d)

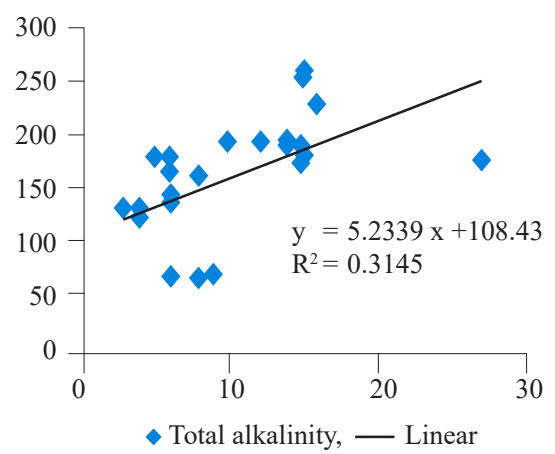

(b)

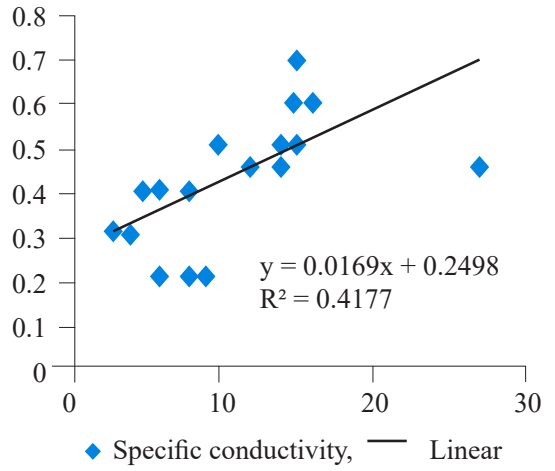

(e)

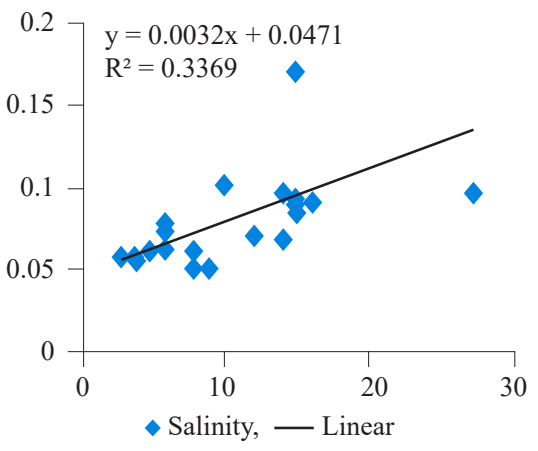

(c)

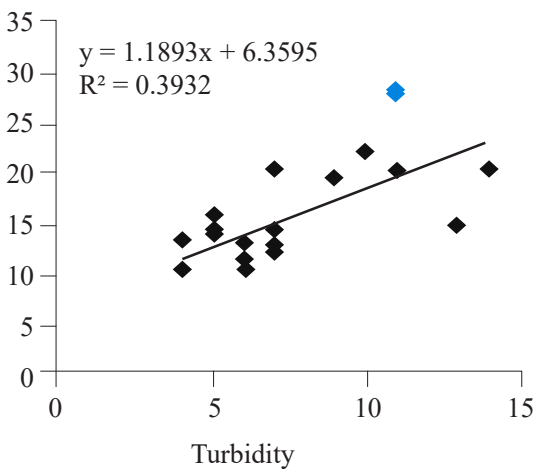

(f)

Fig. 4. Scatter diagrams with linear regression equations to assess water quality parameters

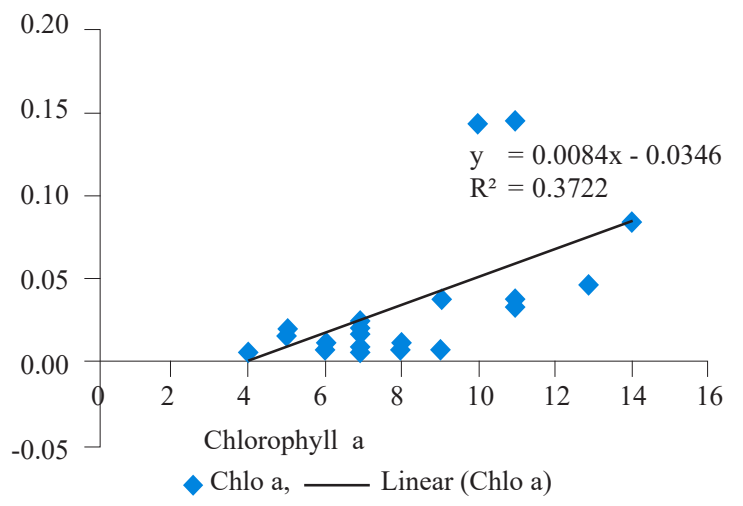

Fig. 5. Scatter diagrams with linear regression equations for estimation of Chlorophyll a alkalinity, chlorinity and salinity. Similarly, short wave infrared band $(1.55-1.70 \mu \mathrm{m})$ is useful for assessing chlorophyll a and turbidity after the images are subjected to atmospheric correction. The models are region and season specific, however, they have the potential for monitoring water quality parameters and chlorophyll a of large water bodies. The information will be useful for policy makers and researchers for chalking out proper management practices to improve productivity of large inland water bodies.

\section{Acknowledgements}

The authors express sincere thanks to the Head, Fisheries Resources and Environment Management Division, ICAR-Central Inland Fisheries Research 
Institute, Barrackpore, Kolkata for providing guidance to carry out the study and anonymous reviewers for their comments and suggestions.

\section{References}

APHA 1992. Standard methods for the examination of water and wastewater, $18^{\text {th }}$ edn. American Public Health Association, Washington DC, USA.

Akbar, T. A., Hassan, Q. K. and Achari, G. 2014. Development of remote sensing based models for surface water quality. CLEAN Soil Air Water, 42(8): 1044-1051.

Alparslan, E., Aydoner, C., Tufekci, V. and Tufekci, H. 2007. Water quality assessment at Omerli Dam using remote sensing techniques. Environ. Monit. Assess., 135(1): 391-398. DOI: 10. 1007/s10661-007-9658-6.

Bierwirth, P. N., Lee, T. J. and Burne, R. V. 1993. Shallow sea-floor reflectance and water depth derived by unmixing multispectral imagery. Photogramm. Eng. Rem. S., 59: 331-38

Chebud, Y., Naja, G. M., Rivero, R. G. and Melesse, A. M. 2012. Water quality monitoring using remote sensing and an artificial neural network. Water Air Soil Poll., 223(8): 4875-4887.

Chen, Q., Zhang, Y. and Hallikainen, M. 2007. Water quality monitoring using remote sensing in support of the EU water framework directive (WFD): A case study in the Gulf of Finland. Environ. Monit. Assess., 124: 157-66.

Chopra, R., Verma, V. K. and Sharma, P. K. 2001. Mapping, monitoring and conservation of Haruke wetland ecosystem, Punjab, India, through remote sensing. Int. J. Remote S., 22(1): 89-98. doi.org/10.1080/014311601750038866.

Choubey, V. K. 1997. Monitoring turbidity with IRS-1A data. Hydrol. Process., 11: 1907-1915.

Dekker, A. G., Vos, R. J. and Peters, S. W. M. 2002. Analytical algorithms for lake water TSM estimation for retrospective analyses of TM and SPOT sensor data. Int. J. Remote Sens. 23: 15-35. doi.org/10.1080/01431160010006917.

Dewidar, K. and Khedr, A. 2001. Water quality assessment with simultaneous Landsat-5 TM at Manzala Lagoon, Egypt. Hydrobiologia, 487: 49-58.

El-Din, M. S., Gaber, A., Koch, M., Ahmed, R. S. and Bahgat, I. 2013. Remote sensing application for water quality assessment in Lake Timsah, Suez Canal, Egypt. J. Remote Sens. Technol., 1(3): 61-74.

Fraser, R. N. 1998. Multispectral remote sensing of turbidity among Nebraska Sand Hills lakes. Int. J. Remote Sens., 19: 3011-16. doi.org/10.1080/014311698214406.

Giardino, C., Bresciani, M., Cazzaniga, I., Schenk, K., Rieger, P., Braga, F., Matta, E. and Brando, V. E. 2014. Evaluation of multi-resolution satellite sensors for assessing water quality and bottom depth of Lake Garda. Sensors, 14: 24116-24131.

Date of Receipt ～: 05.02.2014

Date of Acceptance : 20.03.2019
Gholizadeh, M., Melesse,A. and Reddi,L. 2016. A comprehensive review on water quality parameters estimation using remote sensing techniques. Sensors, 16(8): 1-43. doi:10.3390/s160 81298

Hadjimitsis, D. G. and Clayton, C. R. I. 2008. The use of an improved atmospheric correction algorithm for removing atmospheric effects from remotely sensed images using an atmosphere-surface simulation and meteorological data. Meteorol. Appl., 15(3): 381-387. DOI: 10.1002/met.80. http://www.indiawaterportal.org/book/export/html/78.

Lim, J. and Choi, M. 2015. Assessment of water quality based on Landsat 8 operational land imager associated with human activities in Korea. Environ. Monit. Assess., 187(6): 384.

MWR 2013. Ministry of Water Resources, Government of India. http://wrmin.nic.in/. (Accessed 07 March 2013).

Ouma, Y. O., Waga, J., Okech, M., Lavisa, O. and Mbuthia, D. 2018. Estimation of reservoir bio-optical water quality parameters using Smartphone Sensor Apps and Landsat ETM. J. Sens., 16: 1-32.

Ritchie, J. C. and Charles, M. C. 1988. Comparison of measured suspended sediment concentration estimated from Landsat MSS data. Int. J. Remote Sens., 9(3): 379-387. doi. org/10.1080/01431168808954861.

Ritchie, J. C., Zimba, P. V. and Everitt, J. H. 2003. Remote sensing techniques to assess water quality. Photogramm. Eng. Rem. S., 69(6): 695-704..

Ritchie, J. C., McHenry, J. R,, Schiebe, F. R. and Wilson, R. B. 1974. The relationship of reflected solar radiation and the concentration of sediment in the surface water of reservoirs. In: Shahrokhi, F. (Eds.), Remote sensing of earth resources vol. III. The University of Tennessee Space Institute, Tullahoma, Tennessee, p. 57-72

Schalles, J. F., Gitelson, A. A., Yacobi, Y. Z. and Kroenke, A. E. 1998. Estimation of chlorophyll a from time series measurements of high spectral resolution reflectance in an eutrophic lake. J. Physiol., 34: 383-390. doi.org/10.1046/ j.1529-8817.1998.340383.x.

Sugunan, V. V. 1995. FAO Fisheries technical paper No. 345, Food and Agriculture Organisation, Rome, 423 pp.

Syahreza, S., MatJafri, M. Z., Lim, H. S. and Mustapha, M. R. 2012. Water quality assessment in Kelantan delta using remote sensing technique. In: Kamerman, G. W., Steinvall, O., Lewis, K. L., Hollins, R. C., Merlet, T. J., Gruneisen, M. T., Dusek, M., Rarity, J. G., Bishop, G. J. and Gonglewski, J. (Eds.), Electro-optical remote sensing, photonic technologies, and applications VI, vol. 8542, International Society for Optics and Photonics, p. 8542 doi: $10.1117 / 12.97893$

Zilioli, E. and Brivio, P. A. 1997. The satellite derived optical information for the comparative assessment of lacustrine water quality. Sci. Total Environ., 196: 229-245. doi.org/ 10.1016/S0048-9697(96)05411-3. 